\title{
QUALITY OF LOW FAT PREBIOTIC FROZEN YOGHURT
}

\author{
K.M. Kamaly, K.M.K. Kebary, A.H. El-Sonbaty and Khadega R. Badawi \\ Department of Dairy Sci. and Technol., Faculty of Agriculture, Menoufia University, \\ Shibin El-Kom, Egypt.
}

Received: Feb. 25, 2017

Accepted: Feb. 27,2017

\begin{abstract}
Frozen yoghurt is a complex fermented frozen dairy desert that combines the physical characteristics of ice cream with sensory and nutritional properties of fermented milk products. Six batches of frozen yoghurt were made to study the effect of replacing milk fat with inulin (Frutafit $H D^{\circledR}$ ) on the quality of frozen yoghurt. Control vanilla frozen yoghurt mix containing $4 \%$ fat, $13 \%$ milk solid not fat, $15 \%$ sucrose and $0.5 \%$ stabilizer was prepared. The other 5 batches were made by replacing 20,40,60, 80 and 100\% of milk fat with inulin. The obtained results indicated that replacement of milk fat with inulin increased the acidity, the specific gravity, weight per gallon and viscosity of all mixes and specific gravity, weight per gallon, melting resistance and carbohydrate content of frozen yoghurt and this increase was proportional to the rate of replacement, and decreased $\mathrm{pH}$ values of frozen yoghurt mixes, fat and caloric value of frozen yoghurt, while replacement of milk fat inulin did not affect the ash, total protein and total solids content of frozen yoghurt. Increasing the rate of replacing milk fat with Frutafit $H D^{\circledR}$ up to $60 \%$ increased the overrun and improved the acceptability of the resultant frozen yoghurt, while increasing the rate of the replacement above that decreased the overrun and the scores of organoleptic properties of frozen yoghurt.
\end{abstract}

Key words: Low fat, frozen yoghurt, prebiotic, inulin, fat replacers.

\section{INTRODUCTION}

Frozen yoghurt is a complex fermented frozen dairy desert that combines the physical characteristics of ice cream with sensory and nutritional properties of fermented milk products. This elaboration results in a nutritious product with a refreshing taste and storage stability significantly longer than of yoghurt (Guven and Karaca, 2002). Consumers often choose to eat frozen yoghurt because they expect that it contains less lactose than ice cream and provides health benefits from the viable bacteria contained in it (Marshall, 2001).

Inulin is a unique fat replacer in this regard and can have an important role in improving ice cream texture due to its ability to bind water molecules and form aged network (Franck, 2002; Srisuvor et al., 2013 and Akbari et al., 2016). Inulin is a linear polymer of fructose molecules that usually contains a glucose molecule at its terminal (Khuenpet et al., 2017). Akalin and Erisir
(2008) and Rezaei et al. (2014) reported that prebiotics are non-digestible carbohydrates that resist hydrolysis and absorption in the upper parts of gastrointestinal tract and are metabolized selectively by at least one type of probiotic in the colon (Mattila-Sandholmet al., 2002). Inulin considered as a prebiotic which can cause a specific shift in the composition of the colonic microbiota that has beneficial effects for the human host (Oliveira et al., 2011 and Krasaekoopt and Watcharapoka, 2014). These beneficial effects such as increasing calcium absorption with positive effects for bone health (Meyer and Stass-Wolthuis, 2009), lowering of serum lipids with relevance for heart health (Brighenti, 2007), enhancing resistance to infections (Cummings et al., 2001) and stimulating the immune system (Lomax and Calder, 2009). Inulin has been used as fat replacer, a low caloric bulking agent and as texturizing and water binding agents (Tungland and Meyer, 2002; Kip et al., 2006; Buriti et al., 2010; Meyer et al., 
2011; Oliveira et al., 2011 and Kebary et al., 2015).

In view of the aforementioned the objectives of this study were to evaluate the possibility of making good quality prebiotic low fat frozen yoghurt by replacing milk fat with inulin, which is a prebiotic and to monitor the chemical, physical and sensory changes during storage of frozen yoghurt.

\section{MATERIALS AND METHODS Ingredients:}

Fresh bulk buffalo's milk andcream was obtained by separating fresh buffalo's milk in the pilot plant of Department of Dairy Science and Technology, Faculty of Agriculture, Menoufia University, Shibin ElKom, Egypt. Inulin (Frutafit $\mathrm{HD}^{\circledR}$ ) as fat and sugar replacer (Average Chain Length 8-13 monomers) was gratefully provided by Sensus, Borchwerf, The Netherlands. Sucrose and Vanilla were obtained from local market, Stabilizer (Mercol IC) was obtained from Meer Corporation, North Bergen, NJ, USA, Active Streptococcus thermophiles EMCC 1043, Lactobacillus delbrueckii subsp. Bulgaricus EMCC 1102, were obtained from Cairo Mercin, Ain Shams University, Egypt.

\section{Manufacture of frozen yoghurt:}

Frozen yoghurt batches were made according to Goda et al. (1993). Control frozen yoghurt mix was standardized to contain $4.0 \%$ milk fat, $15.0 \%$ sucrose, $13.0 \%$ milk solids not-fat, $0.5 \%$ emulsifier stabilizer (Mercol) and $0.01 \%$ vanilla. The required amount of skim buffalo's milk for each batch was divided into two portions. The first portion was heat treated in a water bath at $85^{\circ} \mathrm{C}$ for $10 \mathrm{~min}$ and then was cooled to $42^{\circ} \mathrm{C}$, inoculated with $1.5 \%$ Streptococcus thermophiles and 1.5\% Lactobacillus delbrueckii subsp. bulgaricus and was incubated at $42^{\circ} \mathrm{C}$ until coagulated then kept in cooler overnight. The required amount of sucrose, cream, emulsifier, non-fat dry milk to adjust the frozen yoghurt base mix were added to the second portion of fluid skim buffalo's milk with continuous agitation. This mix was heat treated at $85^{\circ} \mathrm{C}$ for 10 min then cooled to $6^{\circ} \mathrm{C} \pm 2$ and kept at same temperature overnight for aging. Frozen yoghurt was manufactured by mixing the first and second portions and vanilla was added to each mix before freezing in an experimental ice cream batch freezer (Cattabriga, Bolongia, Italy). The other five frozen yoghurt treatments were made as described above except 20,40,60, 80 and $100 \%$ of milk fat was replaced with inulin (Frutafit $H D^{\circledR)}$. Inulin (Frutafit $H D^{\circledR}$ ) was added to the first portion of skim buffalo's milk before heat treatment. The resultant frozen yoghurt was packaged in plastic cups and kept in deep freezer at $-18^{\circ} \mathrm{C}$ for $24 \mathrm{hrs}$. for hardening. Frozen yoghurt was stored at $-20^{\circ} \pm 2$ for 10 weeks. Samples from each frozen yoghurt treatment were taken at fresh and every two weeks for chemical and sensory evaluation. The whole experiment was done in triplicate.

\section{Physical and chemical analysis:}

Overrun of the frozen yoghurt was determined according to the method of Arbuckle (1986). The specific gravity of frozen yoghurt mixes and frozen yoghurt samples was determined according to Winton (1958). Weight per gallon of frozen yoghurt mixes in kilogram $(\mathrm{kg})$ was directly calculated according to Burke (1947) and Arbuckle (1986). The melting resistance of frozen yoghurt was determined according to Reid and Painter (1933). The viscosity of frozen yoghurt mixes were measured using coaxial cylinder viscometer (Bohin V88, Sweden). Fat content, titratable acidity and $\mathrm{pH}$ values were determined according to Ling (1963). The $\mathrm{pH}$ value was measured using $\mathrm{pH}$ meter (Jenway LTD, Felsted Dunmow, Essex, UK). Total solids, ash and total protein were determined according to the Official Method (A.O.A.C., 2007). Carbohydrate was calculated by difference. Total energy of frozen yoghurt was calculated based on conversion factors as follows; protein 4, carbohydrate 4, inulin 2 
and fat 9 and expressed as $\mathrm{kcal} / 100 \mathrm{~g}$ frozen yoghurt.

\section{Sensory evaluation:}

Ten panelists from the Staff members and graduated students at the Department of Dairy Science and Technology, Department of Food Science and Technology, Faculty of Agriculture, Menoufia University evaluated the organoleptic properties of each batch of vanilla frozen yoghurt at fresh and at the $2^{\text {nd }}, 4^{\text {th }}, 8^{\text {th }}$ and $10^{\text {th }}$ week of storage period according to score sheets described by Kebary and Hussein (1997).

\section{Statistical analysis:}

Data were analyzed using the completely randomized block design and $2 \times 3$ factorial design. Newman-Keuls Test was used to made the multiple comparisons (Steel and Torrie, 1980) using Costat program. Significant differences were determined at $p$ $<0.05$.

\section{RESULTS AND DISCUSSION Frozen yoghurt mix properties:}

Table (1) shows that the titratable acidity significantly $(p \leq 0.05)$ by increasing the rate of replacing milk fat with inulin (Frutafit $\mathrm{HD}^{\circledR}$ ).

Changes in $\mathrm{pH}$ values of low fat frozen yoghurt mixes were shown in (Table 1). $\mathrm{pH}$ values decreased significantly $(p \leq 0.05)$ by increasing the rate of replacement. This decrease might be due to the stimulating effect of inulin on the growth and activity of yoghurt starter (Akin et al., 2007 and Rezaei et al., 2014).

Replacement of milk fat with inulin caused a marked $(p \leq 0.05)$ increase in viscosity (Table 1). This increase was proportional to the rate of the replacement of milk fat with inulin. The increase of viscosity by adding inulin could be attributed to the capacity of inulin to retain water (Soukoulis et al., 2009 and Rezaei et al., 2014), the interaction of inulin with milk protein that can lead to an increase in the molar mass (Scaller-Povolny and Smith, 2001) and the formation of small aggregates of microcrystals that are able to retain water (Gonzalez-Tomas et al., 2008). These results are in accordance with those reported by Arcia et al. (2010) and Cruz et al. (2013).

of frozen yoghurt mixes increased

Table (1). Effect of replacing milk fat with inulin (Frutafit $H D^{\circledR}$ ) on some properties of frozen yoghurt mixes.

\begin{tabular}{||c|c|c|c|c|c||}
\hline Treatments $^{\mathbf{0}}$ & $\begin{array}{c}\text { Titratable } \\
\text { acidity }\end{array}$ & pH value & $\begin{array}{c}\text { Specific } \\
\text { gravity }\end{array}$ & $\begin{array}{c}\text { Weight per } \\
\text { gallon (kg) }\end{array}$ & $\begin{array}{c}\text { Viscosity } \\
(\mathrm{m} \text { pas) }\end{array}$ \\
\hline $\mathrm{C}^{*}$ & $0.680^{\mathrm{F}}$ & $4.92^{\mathrm{A}}$ & $1.2528^{\mathrm{F}}$ & $4.743^{\mathrm{F}}$ & $263.9^{\mathrm{F}}$ \\
\hline $\mathrm{T}_{1}$ & $0.726^{\mathrm{E}}$ & $4.84^{\mathrm{B}}$ & $1.2531^{\mathrm{E}}$ & $4.744^{\mathrm{E}}$ & $276.4^{\mathrm{E}}$ \\
\hline $\mathrm{T}_{2}$ & $0.741^{\mathrm{D}}$ & $4.80^{\mathrm{B}}$ & $1.2533^{\mathrm{D}}$ & $4.745^{\mathrm{D}}$ & $293.8^{\mathrm{D}}$ \\
\hline $\mathrm{T}_{3}$ & $0.749^{\mathrm{C}}$ & $4.75^{\mathrm{C}}$ & $1.2538^{\mathrm{C}}$ & $4.747^{\mathrm{C}}$ & $344.5^{\mathrm{C}}$ \\
\hline $\mathrm{T}_{4}$ & $0.761^{\mathrm{B}}$ & $4.67^{\mathrm{D}}$ & $1.2540^{\mathrm{B}}$ & $4.748^{\mathrm{B}}$ & $389.1^{\mathrm{B}}$ \\
\hline $\mathrm{T}_{5}$ & $0.782^{\mathrm{A}}$ & $4.56^{\mathrm{E}}$ & $1.2546^{\mathrm{A}}$ & $4.750^{\mathrm{A}}$ & $429.7^{\mathrm{A}}$ \\
\hline
\end{tabular}

- Each value in the table was the mean of three replicates.

- For each effect the different letters in the same column means the multiple comparisons are different from each other, letter $A$ is the highest mean followed by $B, C$,..etc.Significant at 0.05 level $(p \leq 0.05)$.

$\mathrm{C}^{*}=$ Control frozen yoghurt mix made with $4 \%$ milk fat.

$T_{1}, T_{2}, T_{3}, T_{4}$ and $T_{5}$ are frozen yoghurt mixes prepared by replacing $20,40,60,80$ and $100 \%$ of milk fat with inulin (Frutafit $H D^{\circledR}$ ), respectively. 
Replacing milk fat with inulin caused a marked increase $(p \leq 0.05)$ in specific gravity and weight per gallon, this increase was proportional to the rate of replacing milk fat with inulin. These results could be attributed to the higher specific gravity of inulin (Frutafit $\mathrm{HD}^{\circledR}$ ) than that of milk fat (Tarrega and Costell, 2006; Naskar et al., 2010 and Cruz et al., 2013).

\section{Frozen yoghurt properties:}

There were significant $(p \leq 0.05)$ differences among samples in overrun (Table 2). Overrun depends on the amount of air trapped in frozen yoghurt. Replacement of milk fat with inulin (Frutafit $\left.H D^{\circledR}\right)$ caused a significant $(p \leq 0.05)$ increase in overrun of the resultant frozen yoghurt (Table 2). It has been reported that adding inulin during the manufacture of frozen desserts improved the whip ability (Arbuckle, 1986, Rajasckaran and Rajor, 1989 and Hamed et al., 2014). Addition of inulin (Frutafit $H D^{\circledR}$ ) up to $60 \% \quad\left(T_{3}\right)$ increased the overrun significantly $(p \leq 0.05)$ (Rezeai et al., 2014), while increasing the rate of replacing milk fat with inulin (Frutafit $H D^{\circledR}$ ) above $60 \%$ caused a significant $(p \leq$ 0.05 ) decrease of overrun of the resultant frozen yoghurt (Table 2). This decrease in overrun might be due to the increase of viscosity which consequently suppress the ability of frozen yoghurt to retain air (Chang and Hartel, 2002; Sofjan and Hartel, 2004 and Meyer et al., 2011).

Table (2) shows the effect of replacing milk fat with inulin on specific gravity and weight per gallon of fresh frozen yoghurt treatments. Both specific gravity and weight per gallon followed similar trends. Replacing milk fat with inulin caused a slight increase in specific gravity and weight per gallon. Control frozen yoghurt and treatment $\mathrm{T}_{3}$ exhibited the lowest values of specific gravity and weight per gallon, while treatment $T_{5}$ which contained the highest inulin content exhibited the highest values of weight per gallon and specific gravity, while there were no significant differences $(p>$ 0.05 ) between treatments $T_{1}$ and $T_{2}$ and $T_{3}$. These results could be attributed to the higher specific gravity of inulin (Frutafit $\mathrm{HD}^{\circledR}$ ) than that of milk fat (Terrega and Costell, 2006; Cruz et al., 2013 and Hamed et al., 2014), and the negative correlation between overrun and specific gravity and weight per gallon (Kebary, 1996; Badawiet al., 2010 and Kebary et al., 2015).

Table (2). Effect of replacing milk fat with inulin (Frutafit $\mathrm{HD}^{\circledR}$ ) on some properties of frozen yoghurt.

\begin{tabular}{|c|c|c|c|c|c|c|}
\hline \multirow[b]{2}{*}{ Treatments ${ }^{\mathbf{a}}$} & \multirow[b]{2}{*}{ Overrun } & \multirow{2}{*}{$\begin{array}{l}\text { Specific } \\
\text { gravity }\end{array}$} & \multirow{2}{*}{$\begin{array}{l}\text { Weight per } \\
\text { gallon (kg) }\end{array}$} & \multicolumn{3}{|c|}{ Melting Resistance } \\
\hline & & & & $\begin{array}{l}\text { First } \\
60 \mathrm{~min}\end{array}$ & $\begin{array}{c}\text { Next } \\
30 \mathrm{~min}\end{array}$ & $\begin{array}{l}\text { Last } \\
30 \mathrm{~min}\end{array}$ \\
\hline $\mathrm{C}^{*}$ & $59.34^{\mathrm{D}}$ & $0.7290^{\mathrm{DE}}$ & $2.760^{\mathrm{DE}}$ & $37.00^{A}$ & $45.70^{A}$ & $17.30^{\mathrm{F}}$ \\
\hline $\mathrm{T}_{1}$ & $64.91^{\mathrm{BC}}$ & $0.7308^{C D}$ & $2.767^{\mathrm{CD}}$ & $35.60^{B}$ & $44.90^{\mathrm{B}}$ & $19.50^{\mathrm{E}}$ \\
\hline $\mathrm{T}_{2}$ & $69.75^{\mathrm{B}}$ & $0.7311^{\mathrm{C}}$ & $2.768^{C}$ & $34.70^{\mathrm{C}}$ & $43.50^{C}$ & $21.80^{\mathrm{D}}$ \\
\hline $\mathrm{T}_{3}$ & $75.18^{A}$ & $0.7305^{C D}$ & $2.765^{\mathrm{CD}}$ & $33.60^{\mathrm{D}}$ & $42.40^{\mathrm{D}}$ & $24.00^{C}$ \\
\hline $\mathrm{T}_{4}$ & $55.83^{\mathrm{DE}}$ & $0.7841^{\mathrm{B}}$ & $2.969^{B}$ & $32.40^{\mathrm{E}}$ & $41.80^{\mathrm{E}}$ & $25.80^{\mathrm{B}}$ \\
\hline $\mathrm{T}_{5}$ & $50.42^{\mathrm{E}}$ & $0.7953^{A}$ & $3.011^{A}$ & $31.60^{\mathrm{F}}$ & $40.90^{\mathrm{F}}$ & $27.50^{\mathrm{A}}$ \\
\hline
\end{tabular}

" , ${ }^{*}$ See Table (1). 
Melting resistance of resultant frozen yoghurt is expressed in Table (2) as the loss in weight percent of the initial weight. Replacement of milk fat with inulin (Frutafit $H D^{\circledR}$ caused on obvious decrease of the rate of melting resistance at $60 \mathrm{~min}$ and next 30 min which means that increasing the melting resistance of the resultant frozen yoghurt. The increase of melting resistance was proportional to the rate of replacing milk fat with inulin. This might be due to the increase of viscosity and the higher water holding capacity of inulin which binds higher amount of water and left lowest amount of free water that can be melted faster than bound water which consequently increases the melting resistance (Villegas and Costell, 2007; Torres et al., 2010 and Akbari et al., 2016). The melting resistance of all treatments after the last $30 \mathrm{~min}$ had contradictory trend of these of the first 60 min. These results are in agreement with those reported by Kebary and Hussein (1997) and Hamed et al., (2014).

Frozen yoghurt treatments were significantly $(p \leq 0.05)$ different from each other in titratable acidity (Tables 3,7 ).
Treatment $T_{5}$ which contained the highest inulin percent had the highest value of titratable acidity that might be due to the stimulating effect of inulin on lactic acid bacteria (Gibson and Roberfroid, 1995 and Ahmadi et al., 2014) on the other hand titratable acidity of all frozen yoghurt treatments did not change significantly $(p>$ 0.05 ) during ten weeks of storage period ( $p$ $>0.05$ ) (Kebary, et al., 2015).

Changes in $\mathrm{pH}$ value of frozen yoghurt treatments are presented in Tables $(3,7)$. $\mathrm{pH}$ values of frozen yoghurt treatments followed on apposite trend of titratable acidity. Replacing milk fat with inulin (Frutafit $\left.H D^{\circledR}\right)$ caused a significant $(p \leq 0.05)$ decrease in $\mathrm{pH}$ values. The lowest $\mathrm{pH}$ value was for treatment $T_{5}$ which contained the highest percent of inulin. This decrease could be due to the stimulating effect of inulin on the growth of lactic acid bacteria (Akin et al., 2007 and Rezeai et al., 2014). On the other hand, there were no significant changes $(p>0.05)$ in $\mathrm{pH}$ values during the storage period (Kebary, 1996).

Table (3). The effect of replacing milk fat with inulin (Frutafit $\mathrm{HD}^{\circledR}$ ) on titratable acidity and $\mathrm{pH}$ values.

\begin{tabular}{|c|c|c|c|c|c|c|c|c|c|c|c|c||}
\hline \multirow{4}{*}{$\begin{array}{c}\text { Treatments } \\
\text { व }\end{array}$} & \multicolumn{4}{|c|}{ Titratable acidity } & \multicolumn{5}{c|}{$\mathrm{pH}$ values } \\
\cline { 2 - 13 } & 0 & 2 & 4 & 6 & 8 & 10 & 0 & 2 & 4 & 6 & 8 & 10 \\
\cline { 2 - 14 } & \multicolumn{4}{|c|}{ Storage period (weeks) } & \multicolumn{5}{c|}{ Storage period (weeks) } \\
\hline $\mathrm{C}^{*}$ & 0.680 & 0.683 & 0.686 & 0.687 & 0.687 & 0.689 & 4.92 & 4.89 & 4.87 & 4.87 & 4.85 & 4.85 \\
\hline $\mathrm{T}_{1}$ & 0.726 & 0.728 & 0.731 & 0.731 & 0.732 & 0.734 & 4.84 & 4.81 & 4.80 & 4.79 & 4.79 & 4.78 \\
\hline $\mathrm{T}_{2}$ & 0.741 & 0.745 & 0.746 & 0.748 & 0.747 & 0.748 & 4.80 & 4.79 & 4.80 & 4.78 & 4.77 & 4.77 \\
\hline $\mathrm{T}_{3}$ & 0.749 & 0.751 & 0.753 & 0.752 & 0.753 & 0.755 & 4.75 & 4.73 & 4.73 & 4.71 & 4.72 & 4.69 \\
\hline $\mathrm{T}_{4}$ & 0.761 & 0.763 & 0.765 & 0.767 & 0.767 & 0.769 & 4.67 & 4.66 & 4.64 & 4.63 & 4.63 & 4.62 \\
\hline $\mathrm{T}_{5}$ & 0.782 & 0.784 & 0.786 & 0.785 & 0.786 & 0.788 & 4.56 & 4.56 & 4.54 & 4.53 & 4.51 & 4.52 \\
\hline \hline
\end{tabular}

口 , * See Table (1). 
Total solids, total protein and ash contents of frozen yoghurt treatments made with the addition of inulin were not significantly different $(p>0.05)$ from that of control frozen yoghurt which means that replacement of milk fat, total nitrogen and ash of inulin did not affect significantly $(p$ $>0.05$ ) the total solids content of the resultant frozen yoghurt. Total solids, total protein and ash contents of all frozen yoghurt treatments did not change significantly $(p>0.05)$ during storage period (Tables 4, 7). These results are in accordance with those reported by Kebary and Hussein (1999), Badawi et al. (2008) and Kebary et al. (2009).

Fat content of all frozen yoghurt treatments did not change significantly $(p>$ $0.05)$ as the storage period progressed (Tables 5, 7). These results are in accordance with those of Kebary and Hussein (1999), Badawi et al. (2008) and Kebary et al. (2015). On the other hand, there was negative correlation between the fat content and the rate of replacing milk fat with inulin (Frutafit $\mathrm{HD}^{\circledR}$ ), which means that fat content of frozen yoghurt treatments decreased significantly $(p \leq 0.05)$ as the rate of replacing milk fat with inulin (Frutafit $\mathrm{HD}^{\circledR}$ ) increased. Similar results were reported by Hussein et al. (2004) and Hamed et al. (2014).

Carbohydrate content of all frozen yoghurt treatments did not change significantly $(p>0.05)$ during the storage period (Salama and Hassan, 1994; Kebary and Hussein, 1999 and Hamed et al., 2014). Carbohydrate content of all frozen yoghurt treatments increased by substituting milk fat with inulin (Frutafit $\mathrm{HD}^{\circledR}$ ) (Tables 5, 7). Treatment $\mathrm{T}_{5}$ which made by replacing $100 \%$ of milk fat with inulin contained the highest carbohydrate content, these results are in agreement with that reported by Hamed et al. (2014).

Total calories of all frozen yoghurt treatments did not change significantly $(p>$ 0.05 ) as storage period progressed (Hamed et al., 2014 and Kebary et al., 2015). Replacement of milk fat with inulin caused a reduction of total calories of frozen yoghurt treatments. This reduction was proportional to the rate of replacement (Tables 5, 7). Treatment $T_{5}$ which made by adding the highest percent of inulin had the lowest caloric value (Kebary and Hussein, 1999 and Hamed et al., 2014).

Table (4). The effect of replacing milk fat with inulin (Frutafit $\mathrm{HD}^{\circledR}$ ) on total solids, ash content, protein content.

\begin{tabular}{||c|c|c|c|c|c|c|c|c|c||}
\hline \multirow{2}{*}{ Treatments } & \multicolumn{3}{|c|}{ Total solids(\%) } & \multicolumn{3}{c|}{ Ash content(\%) } & \multicolumn{3}{c|}{ Protein content(\%) } \\
\cline { 2 - 10 } & \multicolumn{2}{|c|}{ Storage period (weeks) } & \multicolumn{3}{c|}{ Storage period (weeks) } & \multicolumn{3}{c|}{ Storage period (weeks) } \\
\cline { 2 - 10 } & 0 & 5 & 10 & 0 & 5 & 10 & 0 & 5 & 10 \\
\hline $\mathrm{C}^{*}$ & 35.02 & 34.93 & 34.71 & 1.18 & 1.14 & 1.14 & 5.80 & 5.80 & 5.76 \\
\hline $\mathrm{T}_{1}$ & 35.13 & 35.11 & 34.84 & 1.14 & 1.12 & 1.11 & 5.78 & 5.76 & 5.70 \\
\hline $\mathrm{T}_{2}$ & 35.11 & 34.85 & 34.56 & 1.17 & 1.15 & 1.12 & 5.85 & 5.86 & 5.83 \\
\hline $\mathrm{T}_{3}$ & 34.94 & 34.63 & 34.31 & 1.17 & 1.14 & 1.13 & 5.82 & 5.80 & 5.80 \\
\hline $\mathrm{T}_{4}$ & 35.08 & 34.69 & 34.38 & 1.13 & 1.10 & 1.11 & 5.79 & 5.77 & 5.77 \\
\hline $\mathrm{T}_{5}$ & 34.87 & 34.36 & 34.32 & 1.15 & 1.14 & 1.14 & 5.88 & 5.86 & 5.89 \\
\hline \hline
\end{tabular}

- , * See Table (1). 
Table (5). The effect of replacing milk fat with inulin (Frutafit $\mathrm{HD}^{\circledR}$ ) on fat content, carbohydrate content, and the caloric value.

\begin{tabular}{|c|c|c|c|c|c|c|c|c|c|}
\hline \multirow{3}{*}{$\begin{array}{c}\text { Treatments } \\
\text { 0 }\end{array}$} & \multicolumn{3}{|c|}{ Fat content(\%) } & \multicolumn{3}{|c|}{ Carbohydrate content(\%) } & \multicolumn{3}{|c|}{ Caloric value(K.cal./gm) } \\
\hline & \multicolumn{3}{|c|}{ Storage period (weeks) } & \multicolumn{3}{|c|}{ Storage period (weeks) } & \multicolumn{3}{|c|}{ Storage period (weeks) } \\
\hline & 0 & 5 & 10 & 0 & 5 & 10 & 0 & 5 & 10 \\
\hline$C^{*}$ & 4.1 & 4.1 & 4.0 & 23.94 & 23.89 & 23.81 & 155.86 & 155.66 & 154.28 \\
\hline $\mathrm{T}_{1}$ & 3.3 & 3.2 & 3.3 & 24.91 & 25.03 & 24.73 & 150.86 & 150.36 & 149.82 \\
\hline $\mathrm{T}_{2}$ & 2.5 & 2.5 & 2.5 & 25.59 & 25.34 & 25.11 & 145.06 & 144.10 & 143.04 \\
\hline $\mathrm{T}_{3}$ & 1.6 & 1.6 & 1.7 & 26.26 & 25.91 & 25.68 & 137.92 & 136.44 & 136.42 \\
\hline $\mathrm{T}_{4}$ & 0.8 & 0.7 & 0.7 & 27.42 & 27.12 & 26.80 & 133.40 & 131.46 & 130.18 \\
\hline $\mathrm{T}_{5}$ & 0.2 & 0.1 & 0.1 & 27.64 & 27.26 & 27.19 & 127.88 & 125.38 & 125.22 \\
\hline
\end{tabular}

Scores of organoleptic properties are presented in Table (6). The results indicated that there were a positive correlation between organoleptic scores and the rate of replacement of milk fat with inulin up to $60 \%$ then the total scores decreased significantly $(p \leq 0.05)$. Treatment $T_{3}$ exhibited more creaminess property than other treatments. Although many frozen yoghurt treatments were accepted by the panelists, the most accepted treatment was $T_{3}$ followed by $T_{2}$, $\mathrm{T}_{1}$ and control frozen yoghurt treatment which made by replacing $60,40,20$ and Zero \% of milk fat with inulin (Frutafit $\mathrm{HD}^{\circledR}$ ), respectively then treatment $T_{4}$ and $T_{5}$. These results might be due to the progressive aggregation of inulin crystals especially the long chain inulin which consequently improve the sensory quality of the frozen yoghurt (Tungland and Meyer, 2002 and Torres et al., 2010). The total scores of all treatment did not change significantly $(p>$ 0.05 ) during the first four weeks of storage then decreased slightly $(p \leq 0.05)$ up to the end of storage period. These results are in accordance with those reported by Zedan et al. (2001), Kebary et al. (2004) and Hamed et al. (2014).

It can be concluded that replacement of milk fat with inulin caused an obvious increase in melting resistance and reduction in caloric value and this effect was proportional to the rate of replacement. Increasing the rate of replacement up to $60 \%$ increased the overrun and improved the acceptability of the resultant frozen yoghurt, while increasing the replacement rate above that decreased the overrun and the scores of organoleptic properties. Therefore, it could be recommended that it is possible to make a good quality low-fat, prebiotic frozen yoghurt by reducing the milk fat up to $60 \%$ and reducing caloric value by $13.20 \%$ using the inulin (Frutafit $H D^{\circledR}$ ) as a fat replacer which is also a prebiotic that exhibited a lot of health benefits and bifidogenic effect. 


\begin{tabular}{|c|c|c|c|c|c|c|c|c|}
\hline \multirow{6}{*}{ 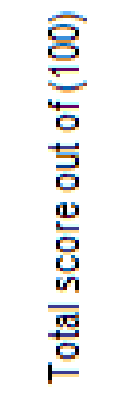 } & \multirow{30}{*}{ 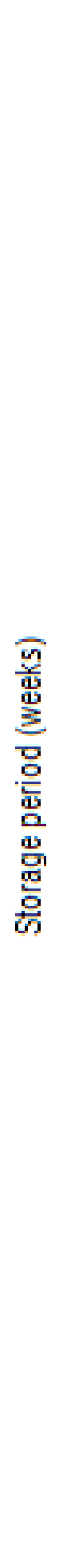 } & 음 & $\mathscr{\circ}$ & $\mathscr{O}$ & ఖ & த & $\mathscr{\infty}$ & $\overleftarrow{\infty}$ \\
\hline & & $\infty$ & 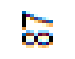 & $\stackrel{\infty}{\infty}$ & I & D & ম & $\widetilde{\infty}$ \\
\hline & & $\omega$ & $\stackrel{\infty}{\infty}$ & ஜ & 8 & ऽ̊ & $\mathscr{O}$ & 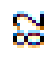 \\
\hline & & $\nabla$ & ร & $\bar{\sigma}$ & I & 8 & த & $\stackrel{\infty}{\infty}$ \\
\hline & & $\sim$ & ऽ & চ & ๙ & 8 & চ̄ & 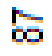 \\
\hline & & 0 & g & 8 & ๖ & $\mathscr{O}$ & 8 & $\stackrel{\infty}{\infty}$ \\
\hline \multirow{6}{*}{ 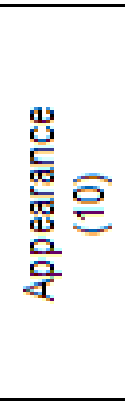 } & & 으 & $r$ & $\infty$ & $r$ & $\infty$ & $r$ & $\infty$ \\
\hline & & $\infty$ & $r$ & $\infty$ & $\infty$ & $\infty$ & $r$ & $\infty$ \\
\hline & & $\infty$ & $\infty$ & $\infty$ & $\infty$ & $\infty$ & $r$ & $r$ \\
\hline & & $\nabla$ & $\infty$ & $\infty$ & $\infty$ & ( & $\infty$ & $r$ \\
\hline & & $\sim$ & $\infty$ & $\infty$ & $\infty$ & os & $\infty$ & $n$ \\
\hline & & 0 & $\infty$ & o & $\infty$ & $\sigma$ & $\infty$ & $\infty$ \\
\hline \multirow{6}{*}{ 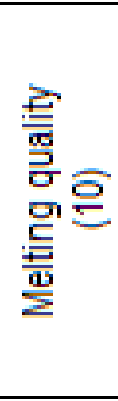 } & & 은 & os & $\infty$ & $\infty$ & os & os & o \\
\hline & & $\infty$ & os & os & $\sigma$ & $\infty$ & $\infty$ & os \\
\hline & & $\infty$ & $\infty$ & $\infty$ & $\infty$ & $\infty$ & $\infty$ & $r$ \\
\hline & & $\nabla$ & $\infty$ & os & $r$ & $\infty$ & $\infty$ & $\infty$ \\
\hline & & $\sim$ & $\infty$ & $\infty$ & $\infty$ & $\infty$ & $\infty$ & $\infty$ \\
\hline & & 0 & $\infty$ & $\infty$ & $\infty$ & 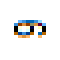 & $r$ & $r$ \\
\hline \multirow{6}{*}{ 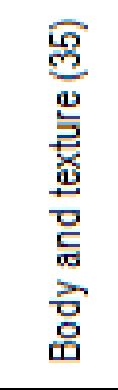 } & & 으 & $\bar{m}$ & প্ & 尺 & க & লি & $\approx$ \\
\hline & & $\infty$ & পি & পి & প্ & $\bar{m}$ & $\bar{m}$ & s \\
\hline & & $\infty$ & $\bar{m}$ & ల & ల & m & $\bar{m}$ & D \\
\hline & & $\nabla$ & ले & ल & ले & m & ले & $\bar{m}$ \\
\hline & & $\sim$ & ले & లี & m & $m$ & $m$ & $\bar{m}$ \\
\hline & & 0 & ले & m & फ & ले & m & $\bar{m}$ \\
\hline \multirow{6}{*}{$\frac{\stackrel{3}{3}}{\stackrel{3}{\square}}$} & & 으 & న్ & 웅 & 昌 & 于 & m & m \\
\hline & & $\infty$ & $\overline{8}$ & 于 & チ & ச & m & $\stackrel{\infty}{m}$ \\
\hline & & $\omega$ & 웅 & $\overline{8}$ & ণ & ア & 웡 & m \\
\hline & & $\nabla$ & ฯ & ษ & テ & ช্ & テ & 广 \\
\hline & & $\sim$ & $\underset{8}{\Im}$ & צ & ช & ア & テ & $\overline{8}$ \\
\hline & & 0 & ? & 寸 & ช & 寸 & $\mathscr{y}$ & アु \\
\hline \multicolumn{3}{|c|}{ ^spuempea $\perp$} & 0 & $\vdash^{-}$ & $\vdash^{-4}$ & $\vdash^{m}$ & $\vdash$ & $\vdash$ \\
\hline
\end{tabular}


Table (7). Statistical analysis of frozen yoghurt properties.

\begin{tabular}{|c|c|c|c|c|c|c|c|c|c|c|c|c|c|c|c|}
\hline \multirow{3}{*}{$\begin{array}{l}\text { Frozen yoghurt } \\
\text { properties }\end{array}$} & \multicolumn{7}{|c|}{ Effect of treatments } & \multicolumn{8}{|c|}{ Effect of storage period (weeks) } \\
\hline & \multicolumn{7}{|c|}{ Multiple comparisons ${ }^{\bullet}$} & \multicolumn{8}{|c|}{ Multiple comparisons ${ }^{\bullet}$} \\
\hline & $\begin{array}{c}\text { Mean } \\
\text { squares }\end{array}$ & $C^{\star}$ & $\mathrm{T}_{1}$ & $\mathrm{~T}_{2}$ & $\mathrm{~T}_{3}$ & $\mathrm{~T}_{4}$ & $\mathrm{~T}_{5}$ & $\begin{array}{c}\text { Mean } \\
\text { squares }\end{array}$ & 0 & 2 & 4 & 5 & 6 & 8 & 10 \\
\hline Titratable acidity(\%) & $0.025^{\star}$ & $\mathrm{F}$ & $E$ & D & $\mathrm{C}$ & $\mathrm{B}$ & $A$ & 0.020 & $A$ & $A$ & A & & A & $A$ & $\mathrm{~A}$ \\
\hline $\mathrm{pH}$ values & $0.439^{*}$ & $A$ & B & $\mathrm{B}$ & $\mathrm{C}$ & D & $\mathrm{E}$ & 0.020 & $A$ & $A$ & A & & A & $A$ & $A$ \\
\hline Total solids (\%) & 0.305 & A & A & A & A & A & $A$ & 1.156 & A & & & A & & & A \\
\hline Ash (\%) & 0.048 & A & A & A & A & $A$ & $\mathrm{~A}$ & 0.089 & $A$ & & & A & & & A \\
\hline Protein (\%) & 0.023 & A & $A$ & $A$ & $A$ & $A$ & $A$ & 0.018 & $A$ & & & $\mathrm{~A}$ & & & $\mathrm{~A}$ \\
\hline Fat (\%) & $20.258^{\star}$ & $A$ & B & C & D & $E$ & $\mathrm{~F}$ & 0.012 & $A$ & & & $\mathrm{~A}$ & & & $\mathrm{~A}$ \\
\hline Carbohydrate (\%) & $15.680^{*}$ & $\mathrm{~F}$ & $E$ & D & C & B & $A$ & 0.273 & $\mathrm{~A}$ & & & A & & & $\mathrm{A}$ \\
\hline Caloric value & $602.865^{\star}$ & $A$ & B & C & $\mathrm{D}$ & $E$ & $\mathrm{~F}$ & 9.652 & A & & & A & & & A \\
\hline \multicolumn{16}{|l|}{$\begin{array}{l}\text { Organoleptic } \\
\text { properties: }\end{array}$} \\
\hline Flavor & $18.733^{*}$ & C & B & $A B$ & A & D & $\mathrm{D}$ & $36.733^{*}$ & A & A & $A B$ & & $\mathrm{~B}$ & $\mathrm{BC}$ & C \\
\hline Body and texture & $18.333^{*}$ & $A$ & $A$ & $A$ & $A$ & $A$ & B & $35.933^{*}$ & $A$ & $A$ & $\mathrm{AB}$ & & $\mathrm{B}$ & $\mathrm{BC}$ & C \\
\hline Melting properties & 0.883 & $A$ & $A$ & A & $A$ & A & $A$ & 3.483 & $A$ & A & A & & A & $A$ & A \\
\hline Appearance & $5.95^{*}$ & $A B$ & A & $A B$ & $\mathrm{~A}$ & $A B$ & B & $3.55^{\star}$ & $A$ & A & $A B$ & & $\mathrm{~B}$ & $\mathrm{BC}$ & C \\
\hline Total scores & $120.15^{\star}$ & B & B & B & $A$ & C & D & 149.35* & $A$ & $A$ & $A B$ & & $\mathrm{~B}$ & $\mathrm{BC}$ & C \\
\hline
\end{tabular}

\section{REFERENCES}

Ahmadi, A., E. Milani, A. Madadlou, S.A. Mortazavi, R.R. Mokarram and D. Salarbashi (2014). Synbiotic yoghurt-ice cream produced via incorporation of microencapsulated Lactobacillus acidophilus (La-5) and fructooligosaccharide. J. Food Sci. and Technol., 51: 1568 - 1574.

Akalin, A.S. and D. Erisir (2008). Effect of inulin and oligofructose on the rheological characteristics and probiotic culture survival in low-fat probiotic ice cream. J. Food Sci., 73: $184-188$.

Akbari, M., M.H. Eskandari, M. Niakosari and A. Bedeltavana (2016). The effect of inulin on the physicochemical properties and sensory attributes of low-fat ice cream. Inter. Dairy J., 57: $52-55$.

Akin, M.B., M.S. Akin and Z. Kirmaci (2007). Effect of inulin and sugar levels on the viability of yoghurt and probiotic bacteria and the physical and sensory characteristics in probiotic ice cream. Food Chem., 104: 93 - 99.

A.O.A.C (2007). Official Method of the Association of Analytical Chemists. $17^{\text {th }}$ Ed. Published by the Association of Official Analytical Chemists, Po. Box 540. Benjamin Franklin Station, Washington, D.C. 20044. 
Arbuckle, W.S. (1986). "Ice Cream" $4^{\text {th }}$ Ed., the AVI publishing Co. INC. West Port. Connecticut, U.S.A.

Arcia, P.H., E. Costell and A. Tarreg (2010). Thickness suitability of prebiotic dairy desserts: Relationship with rheological properties. Food Res. Inter., 43: 2409 2416.

Badawi, R.M., I.I. Badran, K.M.K. Kebary, Seham I. Farag and Afaf Said (2010). Effect of replacing skim milk powder with dried butter milk on ice milk quality. Proc. $11^{\text {th }}$ Egyptian Conf. Dairy Sci. and Technol., pp. $511-521$.

Badawi, R.M., A.I. Hamed, K.M.K. Kebary and Hweda A. El-Sayed (2008). Effect of replacing milk fat with fat replacers on the quality of stirred yoghurt. Egyptian J. Diary Sci., 36: 197 - 206.

Brighenti, F. (2007). Dietary fractans and serum triacylglycerols: a meta-analysis of randomized controlled trials. J. Nutr., 11: 2552 - 2556.

Buriti, F.C.A., I.A. Castro and S.M.I. Saad (2010). Effects of refrigeration, freezing and replacement of milk fat by inulin and whey protein concentrate on texture profile and sensory acceptance of synbiotic guava mousses. Food Chem., 123: 1190 - 1197.

Burke, A.D. (1947). "Practical Ice Cream Making." The Olsen Publishing Co. Milwaukee, Wis. U.S.A.

Chang, Y. and R.W. Hartel (2002). Development of air cells in a batch ice cream freezer. J. Food Eng., 55: 71 - 78.

Cruz, A.G., R.N. Cavalcanti, L.M. Guerreiro, A.S. Santana, L.C. Nogueira, C.A. Olieveira, R. Deliza, R.L. Cunha, J.A. Faria and H.M. Bolini (2013). Developing a prebiotic yoghurt: Rheological, physicchemical and microbiological aspects and adequacy of survival analysis methology. J. Food Eng., 114: 323 - 330.

Cummings, J.H., S. Christie and T.J. Cole (2001). A study of fructo oligosaccharides in the prevention of travellers'diarrhoeo. Alimentary Pharmacology and Therapeutics, 15: $1139-1145$.
Franck, A. (2002). Technological functionality of inulin and oligofructose. British J. Nutr., 87: $287-291$.

Gibson, G.R. and M.B. Roberfroid (1995). Dietary modulation of the human colonic microbiota: Introducing the concept of prebiotics, J. Nutr., 125: $1401-1412$.

Goda, E., I.A. Att, S.A. Salem and M.S. Kamar (1993). Studies on frozen yoghurt manufacturing method. Egyptian J. Food Sci., 2: 157 - 166.

Gonzalez-Tomas, L., J. Coll-Marques and E. Costell (2008). Viscoelasticity of inulinstarch-based dairy systems. Influence of inulin average chain length. Food Hydrocolloids, 22: $1372-1380$.

Guven, M. and O.B. Karaca (2002). The effects of varying sugar content and fruit concentration on the physical properties of vanilla and fruit ice cream type frozen yoghurts. Inter. J. Dairy Technol., 55: 27 $-31$.

Hamed, A.I., K.M.K. Kebary, R.M. Badawi, O.M. Salem and Nevein S. Omar (2014). Manufacture of low fat prebiotic ice milk. Menoufia J. Agric. Res., 39: 1317 - 1329.

Hussein, S.A. and R.M. Badawi (1999). Effect of fat substitutes on physicco, chemical and organoleptic properties of low fat ice milk. Menoufia J. Agric. Res., 24: 923 - 935.

Hussein, S.A., R.M. Badawi and I.I. Badran (2004). Quality of fat free yoghurt made with fat repalcers. Menoufia J. Agric. Res., 29: 1295 - 1315.

Kamaly, K.M., K.M.K. Kebary, A.H. ElSonbaty and Khadega R.M. Badawi (2011). Effect of fortification ingredients on the quality of yoghurt made from cow's milk. Menoufia J. Agric. Res., 36: 1591 1609.

Kebary, K.M.K. (1996). Viability of Bifidobacterium bifidum and its effect on quality of frozen zabady. Food Res. Inter., 29: 431 - 439.

Kebary, K.M.K. and S.A. Hussein (1997). Quality of ice cream as influenced by substituting non-fat dry milk whey-bean 
proteins coprecipitates. Egyptian J. Dairy Sci., 25: $311-325$.

Kebary, K.M.K. and S.A. Hussein (1999). Manufacture of low fat Zabady using different fat substitutes. Acta Alimentaria, 28: $1-14$.

Kebary, K.M.K., R.M. Badawi, S.F. Mahmoud and A.S. El-Sisi (2009). Manufacture of low fat Domiati cheese using fat mimetics. Menoufia J. Agric. Res., 34: 1887 - 1899.

Kebary, K.M.K., A.I. Hamed, R.M. Badawi, O.M. Salem and Nevein S. Omar (2015). Preparation and properties of low-fat ice milk fortified with inulin. Egyptian J. Dairy Sci., 43: 169 - 176.

Kebary, K.M.K., S.A. Hussein and R.M. Badawi (2004). Impact of fortification of cow's milk with a modified starch on yoghurt quality. Egyptian J. Dairy Sci., 32: 111 - 124.

Khuenpet, K., M. Fukuoka, W. Jittanit and S. Sirisansaneeyakul (2017). Spray drying of inulin component extracted from Jerusalem artichoke tuber powder using conventional and ohmic-ultrasonic heating for extraction process. J. Food Eng., 194: 67 - 78.

Kip, P., D. Meyer and R.H. Jellema (2006). Inulin simprovesunsoric and textural properties of low-fat yoghurts. Inter. Dairy J., 16: 1098 - 1103.

Krasaekoopt, W. and S. Watcharapoka (2014). Effect of addition of inulin and galactooligo saccharide on the survival of microencapsulated probiotics in alginate beads coated with chitosan in stimulated digestive system-yoghurt and fruit juice. LWT-Food Sci. and Technol., 57: 761 766.

Ling, E.R. (1963). A Text Book of dairy Chemistry, Vol. 2 Practical $3^{\text {rd }}$ ed. Chapman \& Hall, Ltd., London.

Lomax, A. and P.C. Calder (2009). Prebiotics, immune function, infection and inflammation: A review of the evidence. British J. Nutr., 101: $633-658$.

Marshall, R.T. (2001). Frozen dairy desserts. In: Marth, E.H.; Steele, J.L. (eds). Applied dairy microbiology. Deecer Press, New York, pp. $93-127$.

Mattila, T. Sandholm, P. Myllarinen, R. Crittenden, G. Mogensen, R. Fonden and M. Sarrela (2002). Technological challenges for future probiotic foods. Inter. Dairy J., 12: 173 - 182.

Meyer, D. and M. Stasse-Woltuis (2009). The bifidogenic effect of inulin and oligofructose and its consequences for gut-health, European J. Clinical Nutr., 63: $1277-1289$.

Meyer, D., S.A. Bayarri, A. Tarrega and E. Costell (2011). Inulin as texture modifier in dairy products. Food Hydrocolloids, 25: 1881 - 1890.

Naskar, B., A. Dan, G. Soumen and S.P. Moulik (2010). Characteristic physiochemical features of the biopolymer inulin in solvent added and deplted states. Carbohydrate Polymers, 81: 700 - 706 .

Oliveira, C., M.R.D. Guimaräes and L. Domingues (2011). Recombinant microbial systems for improved Bgalactosidase production and biotechnological applications. Biotechnol. Adv., 29: $600-609$.

Rajasckaran, M. and R.B. Rajor (1989). Manufacture of frozen yoghurt like products from soybean and skim milk / butter milk solids. Indian J. Dairy Sci., 42: $132-135$.

Reid, W.H.E. and W.E. Painter (1933). "The freezing properties, stability and physical quality of chocolate ice cream". Missouri, Agric. Exp. Sta. Bull., p. 185.

Rezaei, R., M. Khomeiri, M. Alami and M. Kashaninejad (2014). Effect of inulin on the physicochemical properties, flow behavior and probiotic survival of frozen yoghurt. J. Food Sci. and Technol., 51: $2809-2814$.

Roberfroid, M.B. (2000). Prebiotics and probiotics: are they functional foods? American. J. Clinical. Nutr., 71: 1682 1687.

Salama, F.M.M. and F.A.M. Hassan (1994). Manufacture of new yoghurt like 
products. Egyptian J. Dairy Sci., 22: 31 38.

Schaller-Povolny, L.A. and D.E. Smith (2001). Viscosity and freezing point of a reduced fatice cream mix as related to inulin content. Milchwissenschaft-Milk Sci. Inter., 56: $25-29$.

Sofjan, P. Rosalina and Richard, W. Hartel (2004). Effects of overrun on structural and physical characteristics of ice cream. Inter. Dairy J., 14: 255 - 262.

Soukoulis, C., D. Lebesi and C. Tzia (2009). Enrichment of ice cream with dietary fibre: Effects on rheological properties, ice crystallization and glass transition phenomena. FoodChem., 115: 665 671.

Srisuvor, N., N. Chinprahast, C. Prakitchaiwattana and $\mathrm{S}$. Subhimaros (2013). Effects of inulin and polydextrose on physicochemical and sensory properties of low-fat set yoghurt with probiotic-cultured banana purée LWTFood Sci. and Technol., 51: $30-36$.

Tarrega, A. and E. Costell (2006). Effect of inulin addition on rheological and sensory properties of fat-free starch-based dairy results. Inter. Dairy J., 16: $1104-1112$.

Torres, J.D., A. Tarrega and E. Costell (2010). Storage stability of starch-based dairy desserts containing longchaininulin: Rheology and particle size distribution. Inter. Dairy J., 20: $46-52$.

Tungland, B.C. and D. Meyer (2002). Non digestible oligo- and polysaccharides (dietary fiber): Their physiology and role in human health and food, Comprehensive Reviews in Food Sci. and Food Safety, 1: $73-92$.

Villegas, B. and E. Costell (2007). Flow behaviour of inulin-milk beverages. Influence of inulin average chain length and of milk fat content. Inter. Dairy J., 17: $776-781$.

Winton, A.L. (1958). Analysis of Foods. $3^{\text {rd }}$ printing \{p. 6\} John Wiley and Sons Ince. New York.

Zedan, M.A., A.N. Zedan, K.M.K. Kebary and S.F. Mahmoud (2001). Effects of fortification of cow's milk with acetylated whey protein concentrates on the quality of set yoghurt. Egyptian J. Dairy Sci., 29: $285-297$. 


\section{جودة اليوجورت المجمد المنخفض الدهن واللداعم للحيوية}

كمال محمد كمالى ، خميس محمد كامل كعبارى ، على حسن السنباطى ، خديجة رجب باوى

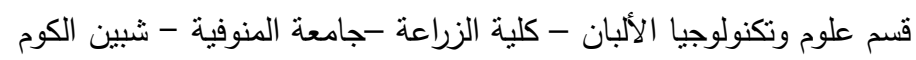

\section{الملخص العربى}

اهتمت الدراسة فى هذا الجزء بدراسة تأثير إستبدال دهن اللبن بنسٍ مُختلفةٍ بواسطة الإنيولين (Frutafit HD)

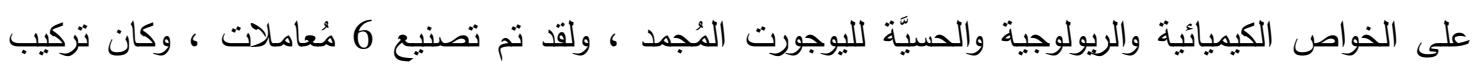
المُعاملة الكنترول كالتالى :

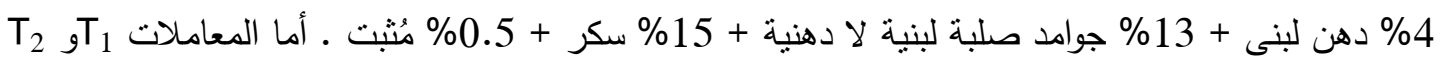

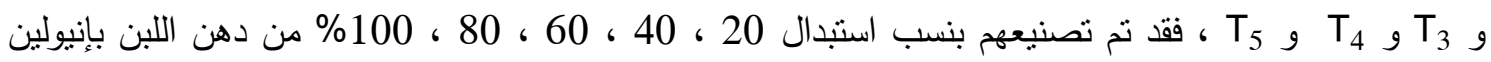
وتم تخزين المُعاملات فى الفريزر على -20 (Frutafit HD ${ }^{\circledR}$ ) طازجة وبعد 2 ، 4 ، 5 ، 6 ، 8 ، 10 أسابيع وذللك لإجراء التحليلات الكيماوية والريولوجية والحسية عليها. ولقد أوضحت النتائج المُتحصل عليها بعد تحليلها إحصائياً ما يلى :

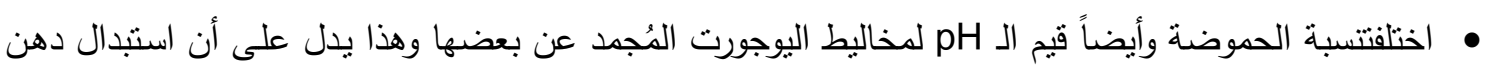

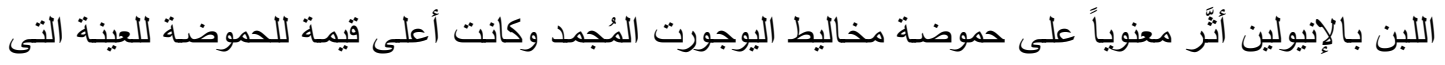

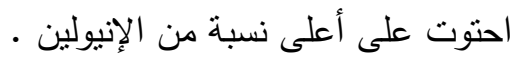

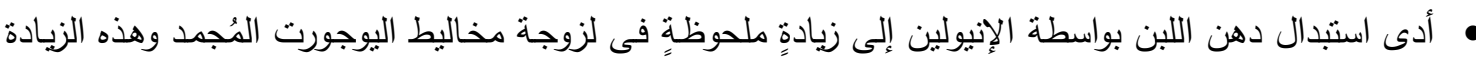

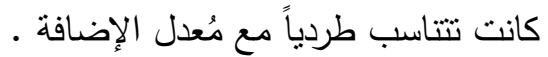

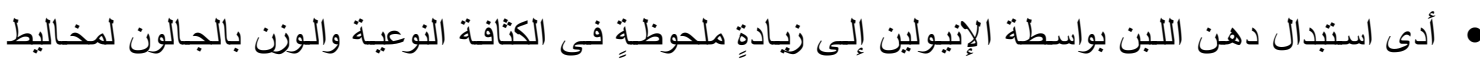

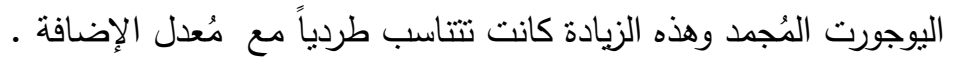

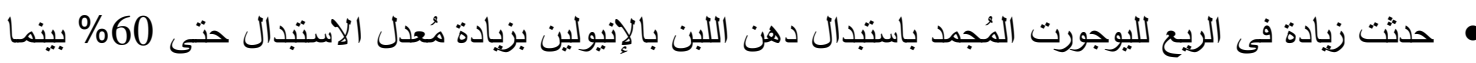

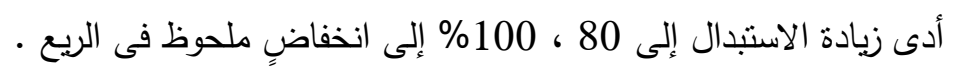

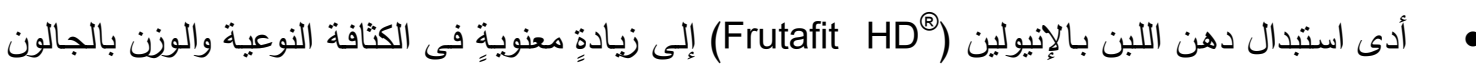
لليوجورت المُجمد بزيادة مُعدل الاستبدال ـ

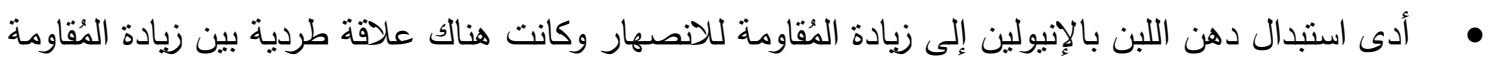

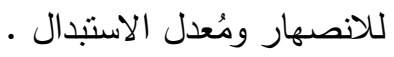

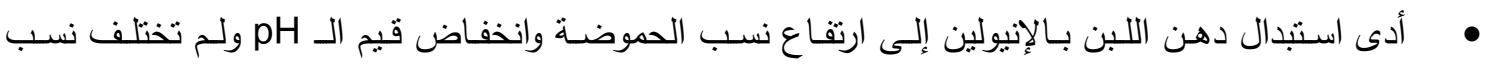

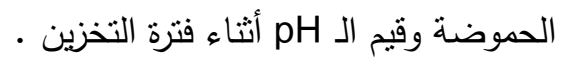

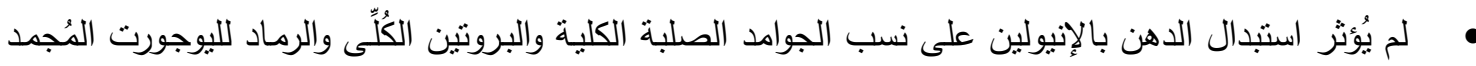
• ومن ناحيةٍ أخرى لم تتأثر نسب الجوامد الصلبة والبروتين الكلى والرماد معنوياً فى كل المعاملات أثناء فترة 


\section{Kamaly, et al.,}

• احتوت العينة الكنترول على أعلى نسبة للاهن بينما حدث انخفاض فى الدهن بخفض الدهن فى اللبن • ولم

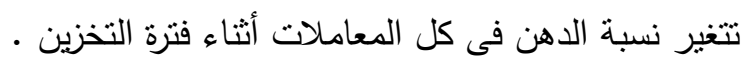

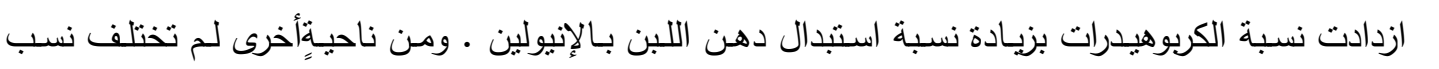
الكربوهيدرات معنوياً فى كل المعاملات أثناء فترة التخزين • • •

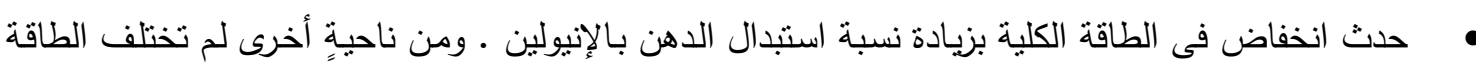
الكلية فى كل العينات معنويا أثناء فترة التخزين •

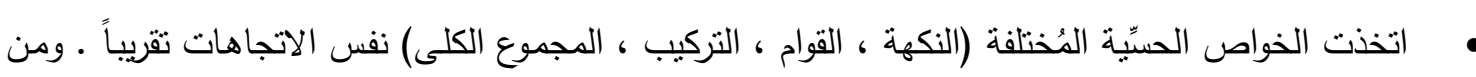

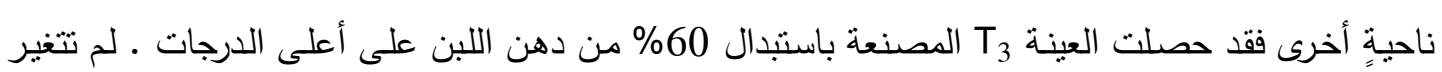

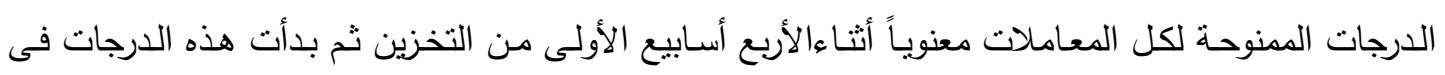

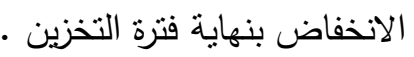

